\title{
Determination of glutamic acid decarboxylase (GAD65) in pancreatic islets and its in vitro and in vivo degradation kinetics in serum using a highly sensitive enzyme immunoassay
}

\author{
Michael Schlosser ${ }^{\mathrm{a}, \mathrm{b}, *}$, Uwe Walschus ${ }^{\mathrm{a}, \mathrm{b}}$, Ingrid Klöting ${ }^{\mathrm{c}}$ and Reinhard Walther ${ }^{\mathrm{a}}$ \\ ${ }^{a}$ Department of Medical Biochemistry and Molecular Biology, Ernst Moritz Arndt University of Greifswald, \\ Karlsburg, Germany \\ ${ }^{\mathrm{b}}$ Institute of Pathophysiology, Ernst Moritz Arndt University of Greifswald, Karlsburg, Germany \\ ${ }^{\mathrm{c}}$ Department of Laboratory Animal Science, Ernst Moritz Arndt University of Greifswald, Karlsburg, Germany
}

\begin{abstract}
Glutamic acid decarboxylase GAD65 autoantibodies (GADA) are an established marker for autoimmune diabetes. Recently, the autoantigen GAD65 itself was proposed as biomarker of beta-cell loss for prediction of autoimmune diabetes and graft rejection after islet transplantation. Therefore, the GAD65 content in pancreatic islets of different species and its serum degradation kinetics were examined in this study using a sensitive immunoassay. GAD65 was found in quantities of 78 (human), 43.7 (LEW.1A rat) and 37.4 (BB/OK rat) ng per 1,000 islets, respectively, but not in mouse islets. The in vitro half-life of porcine GAD65 and human recombinant GAD65 ranged from 1.27 to 2.35 hours at $37^{\circ} \mathrm{C}$ in human serum, plasma and blood, and was unaffected by presence of GAD65 autoantibodies. After injecting 2,000 ng recombinant human GAD65 into LEW.1A rats, the in vivo half-life was 2.77 hours. GAD65 was undetectable after 24 hours in these animals, and for up to 48 hours following diabetes induction by streptozotocin in LEW.1A rats. Estimated from these data, at least 13 islets in rat and 1,875 in human must be simultaneously destroyed to detect GAD65 in circulation. These results should be taken into consideration in further studies aimed at examining the diagnostic relevance of GAD65.
\end{abstract}

Keywords: GAD65 determination, ELISA, pancreatic islets, half-life, streptozotocin

\section{Introduction}

In 1990, glutamic acid decarboxylase (GAD) was identified as an autoantigen in type 1 diabetes [1], with GAD65 as the main immunogenic form in humans [2, 3]. Autoantibodies to GAD65 (GADA) can be detected in high prevalence in sera of newly diagnosed patients with type 1 diabetes but also in prediabetic sub-

${ }^{*}$ Corresponding author: Dr. M. Schlosser, Department of Medical Biochemistry and Molecular Biology, Ernst Moritz Arndt University of Greifswald, Greifswalder Str. 11c, D-17495 Karlsburg, Germany. Tel.: +49 3834 8619178; Fax: +49 3834 8680118; E-mail: schlosse @uni-greifswald.de. jects [4] and in patients with latent autoimmune diabetes of adulthood (LADA) [5]. Apart from the central nervous system, significant amounts of GAD65 are largely restricted to the cytoplasm of islet beta cells. Therefore, the occurrence of GADA is a secondary reaction after GAD65 release into circulation and exposure to the immune system. Hence the detection of GAD65 in serum could possibly serve as a diagnostic marker for detection of acute beta-cell loss in the prediabetic phase, preceding and/or accompanying the occurrence of GADA, but also for detection of betacell destruction resulting from graft rejection after islet transplantation. The latter application has already been examined in an experimental study of islet transplan- 
tation using an enzymatic assay format [6]. However, compared to enzymatic assays the application of immunoassays would provide a better sensitivity and reproducibility as well as a higher throughput.

Whereas several assays for the detection and quantification of GADA using different immunoassay formats and reagents have been described [3-5,7-9] and evaluated in the Diabetes Antibody Standardization Program [10], quantitative determination of the autoantigen GAD65 itself has been given less priority. An enzyme-linked immunosorbent assay (ELISA) using two monoclonal antibodies has been performed in a study to characterize purified recombinant GAD65 after expression in insect cells [11], but the sensitivity of the assay was insufficient to detect GAD65 in serum. A radioimmunoassay using a polyclonal rabbit anti-GAD65-serum was described [12], but the authors concluded that the assay, with a detection limit of 1$3 \mathrm{ng} / \mathrm{ml}$ GAD65, was probably not sensitive enough to detect circulating GAD65 in serum samples. Another recently described magnetic-bead based chemiluminescence assay with a detection limit between 27 and $31 \mathrm{pg} / \mathrm{ml}$ used a monoclonal antibody as primary antibody and a polyclonal serum for detection of bound GAD65 [13]. In addition to the hundredfold better sensitivity compared to the radioimmunoassay mentioned above, the capture antibody in that assay was specifically chosen for the only molecular region known to be not significantly targeted by GADA. It should thereby avoid interference from these autoantibodies when examining samples from prediabetic subjects. However, while the authors demonstrated the compatibility of the assay with serum and plasma, they did not provide any results on the kinetics of GAD65 degradation in vitro or in vivo.

Since a number of monoclonal antibodies with a high affinity and specificity for the GAD65 isoform (antiGAD65-MAbs) are available [14,15], we developed an ELISA based on a set of two anti-GAD65-MAbs with the sensitivity of $30 \mathrm{pg} / \mathrm{ml}$ as the magnetic-bead based assay mentioned above [16]. Based on this assay, the aim of this experimental study was to analyze the GAD65 content of pancreatic islets of different species, and to examine the degradation kinetics and the in vitro half-life of GAD65 in human serum, plasma and whole blood samples as well as the in vivo half-life in the circulation of rats. Additionally, we determined the GAD65 level in rat sera after acute beta-cell loss induced by application of streptozotocin. The results of this investigation should provide first insights to assess the diagnostic value of GAD65 as a marker of acute beta-cell loss in prediabetes or transplant rejection.

\section{Materials and methods}

\subsection{Laboratory animals}

Female LEW.1A rats (age 100-110 d) were used in the in vivo experiments and maintained in our animal facility under conventional conditions. All aspects of the animal experiments were conducted in accordance with the animal protection law of the Federal Republic of Germany in its new version of 1 January 1987, with the principles of care for animals in laboratories (drawn up by the National Society for Medical Research) and with the Guidelines for Keeping and Using Laboratory Animals (NIH Publication No.80-23, revised 1985).

\subsection{GAD65 detection in islets extracts}

Human islets were kindly donated by the Islet Transplantation Group of the Department of Medicine, University of Giessen, Germany (Prof. R.G. Bretzel). Islets of neonatal NOD mice, Balb/c mice, LEW.1A rats and $\mathrm{BB} / \mathrm{OK}$ rats (all animals were bred in-house) were prepared by fractionated collagenase digestion of pancreata. 1,000 islets of human, rat and mouse, respectively, were sonicated on ice $(3 \times$ $15 \mathrm{sec}$; SONOPLUS HD70, MS 73; $156 \mathrm{~W} / \mathrm{cm}^{2}$ ) in lysis buffer at $\mathrm{pH} 7.4$ containing $25 \mathrm{mM} / 1$ sodium phosphate, $0.2 \mathrm{mM} / 1$ pyridoxal-5' -phosphate (Merck, Darmstadt, Germany), $1 \mathrm{mM} / 1$ EDTA (Berlin Chemie AG, Berlin, Germany), $1 \mathrm{mM} / \mathrm{l}$ phenylmethylsulfonylfluoride (Sigma, St. Louis, USA), 1 mM/l (2aminoethyl)-isothiouroniumbromid (Sigma, St. Louis, USA) and $1 \%$ Triton X-100. The sonicated preparations were ultracentrifuged once at $100,000 \mathrm{xg}$. Total protein contents were determined using Lowry's method.

\subsection{Examination of the degradation kinetics of GAD65 in vitro and in vivo}

A pig cerebellum extract was prepared by tissue homogenization with an Ultra-Turrax (TP 18/10, 100W) for $5 \times 15 \mathrm{sec}$ on ice in the same lysis buffer as described above at a $1 / 5$ ratio $(\mathrm{w} / \mathrm{w})$. The extract was precleared at 3,000xg followed by ultracentrifugation $(2 \mathrm{x})$ at $100,000 x g$. The GAD65 concentration of the extract was $2,772 \mathrm{ng} / \mathrm{ml}$. Serum, plasma and blood of a healthy human blood donor were incubated for $24 \mathrm{~h}$ by shaking at $37^{\circ} \mathrm{C}$ and $4^{\circ} \mathrm{C}$ with the extract (ratio 1/1). Samples were taken after 5.5, 11, 22, $45 \mathrm{~min}$, and 1.5, $3.0,6.0,12.0$, and $24.0 \mathrm{~h}$ and immediately snap frozen. 
Additionally, aliquots of human recombinant GAD65 (Diamyd Medical AB, Stockholm, Sweden) containing 2,500 ng GAD65/ml were incubated at $37^{\circ} \mathrm{C}$ with serum samples from five healthy human blood donors and one GADA-positive serum from a patient with type 1 diabetes. Sample drawing followed the same time schedule as above.

Furthermore, 2,000 ng of human recombinant GAD65 per $400 \mu \mathrm{l}$ of $25 \mathrm{mM} / 1$ sodium phosphate buffer containing $0.2 \mathrm{mM} / 1$ pyridoxalphosphate, $1 \mathrm{mM} / \mathrm{l} \mathrm{ED-}$ TA, $1 \mathrm{mM} / \mathrm{l}$ (2-aminoethyl)-isothiouroniumbromid ( $\mathrm{pH}$ 7.4), was injected i.v. into the tail vein of each of three rats. Blood was drawn from the retro-orbital sinus after $2.5,7,19,45 \mathrm{~min}$, and 1.5, 3.0, 6.0, 12.0, and 24.0 h. Plasma was separated by centrifugation and immediately snap frozen. Control animals received buffer alone or a GAD65-free solution which was prepared by heating GAD65 for $15 \mathrm{~min}$ at $70^{\circ} \mathrm{C}$.

\subsection{GAD65 detection in serum after beta-cell destruction}

To detect GAD65 in serum after acute beta-cell destruction, four rats received one i.p. application of streptozotocin (STZ; $50 \mathrm{mg} / \mathrm{kg}$ body weight). Blood was drawn from the retro-orbital sinus at $0,8,24$, and $48 \mathrm{~h}$, and blood glucose levels were determined using an automatic analyzer. The plasma was separated and immediately snap frozen. At a blood glucose level above $20 \mathrm{mmol} / \mathrm{l}$, the animals were considered to be diabetic.

\subsection{Monoclonal GAD65 antibody based quantitative GAD65-ELISA}

The anti-GAD65-MAb M63/2H3D9 $\left(\operatorname{IgG}_{2 A} ; 45.2 \pm\right.$ $4.0 \mathrm{mg} \mathrm{Ig} / \mathrm{ml}$ ) was obtained after repeated immunization of a female Balb/c mouse with a GAD65 sequence of 91 amino acids from the N-terminus [17]. The antiGAD65-MAb M61/7E11 ( $\left.\operatorname{IgG}_{1} ; 23.3 \pm 3.0 \mathrm{mg} \mathrm{Ig/ml}\right)$ was derived from a non-obese diabetogenic (NOD) mouse by treatment with a single intraperitoneal injection of a non-diabetic dose of $80 \mathrm{mg} / \mathrm{kg}$ body weight STZ. It recognizes a linear epitope within amino acids 4-17 of the N-terminal region of the GAD65 molecule and is detectable by Western blot analysis as previously detailed [15]. Both antibodies do not interfere with each other as demonstrated by epitope specificity testing based on comparison of single vs. simultaneous binding in an ELISA with solid-phase coated human recombinant GAD65 [16]. No crossreactivity to GAD67 was observed for either of these Abs.
Both anti-GAD65-MAbs were purified by fractionated ammonium sulphate precipitation (28\% and $45 \%$ ). $1 \mathrm{mg} / \mathrm{ml}$ of M61/7E11 was biotinylated with $50 \mu \mathrm{g}$ of biotin-X-NHS (Calbiochem GmbH, Frankfurt, Germany) for $30 \mathrm{~min}$.

The ELISA was performed as described previously [16]. Briefly, high binding microtiter plates (Greiner, Nürtingen, Germany) were coated with M63/2H3D9 ( $25 \mu \mathrm{g} / \mathrm{ml}$ in $50 \mathrm{mM} / 1$ sodium carbonate buffer, $\mathrm{pH} 9.6$, $50 \mu \mathrm{l} /$ well) overnight at $4{ }^{\circ} \mathrm{C}$. After washing twice with phosphate-buffered saline containing $0.05 \%$ Tween 20 (PBST), plates were blocked by $100 \mu \mathrm{l} /$ well PBST/20\% neonatal calf serum (NCS) for $1 \mathrm{~h}$ at room temperature (RT). After washing, dilutions of the standard (recombinant human GAD65; $25 \mathrm{ng} / \mathrm{ml}$ to $0.011 \mathrm{ng} / \mathrm{ml}$, dilution factor 2) and samples in PBST/5\% NCS were incubated for $2 \mathrm{~h}$ at RT under shaking. After washing, the biotinylated M61/7E11 was added (dilution 1/1,000 in PBST with 5\% NCS, $50 \mu \mathrm{l} /$ well) and incubated for $2 \mathrm{~h}$ at RT followed by washing and by incubation with alkaline phosphatase-conjugated streptavidin (1/1,000; Jackson Immunores. Lab, Wilmington, USA) for $1 \mathrm{~h}$ at RT. After washing, the chromogenic substrate solution containing $2.7 \mathrm{mM} / 1$ p-nitrophenyl phosphate (Sigma, St. Louis, USA) in $1 \mathrm{M} / 1$ diethanolamine $/ 0.5 \mathrm{mM} / 1$ $\mathrm{MgCl}_{2}$ buffer ( $\mathrm{pH} 9.8$ ) was added. Optical density (O.D.) was measured at $405 \mathrm{~nm}$ (test wave length) and $630 \mathrm{~nm}$ (reference wave length) by a Dynatech reader MRX Revelation. The detection limit amounted to 30 pg GAD65/ml corresponding to 1.5 pg GAD65 or 0.023 fmol per microtitre plate well [16]. The intraassayreliability was $3.8 \%$ (20 determinations per plate), and the interassay-reliability was $9.8 \%$ (20 determinations over 20 days).

\subsection{Statistical analysis}

Degradation kinetic curves were generated by nonlinear regression analysis using the GraphPad Prism4 program (GraphPad Software, Inc., San Diego). The in vitro and in vivo half-life are equivalent to the EC50 values of these curves, and their $95 \%$ confidence intervals (CI) are given.

\section{Results}

\subsection{GAD65 detection in islets from different species}

Examining the GAD65 content of different species, the highest amount was found in human islets, 78.0 ng 

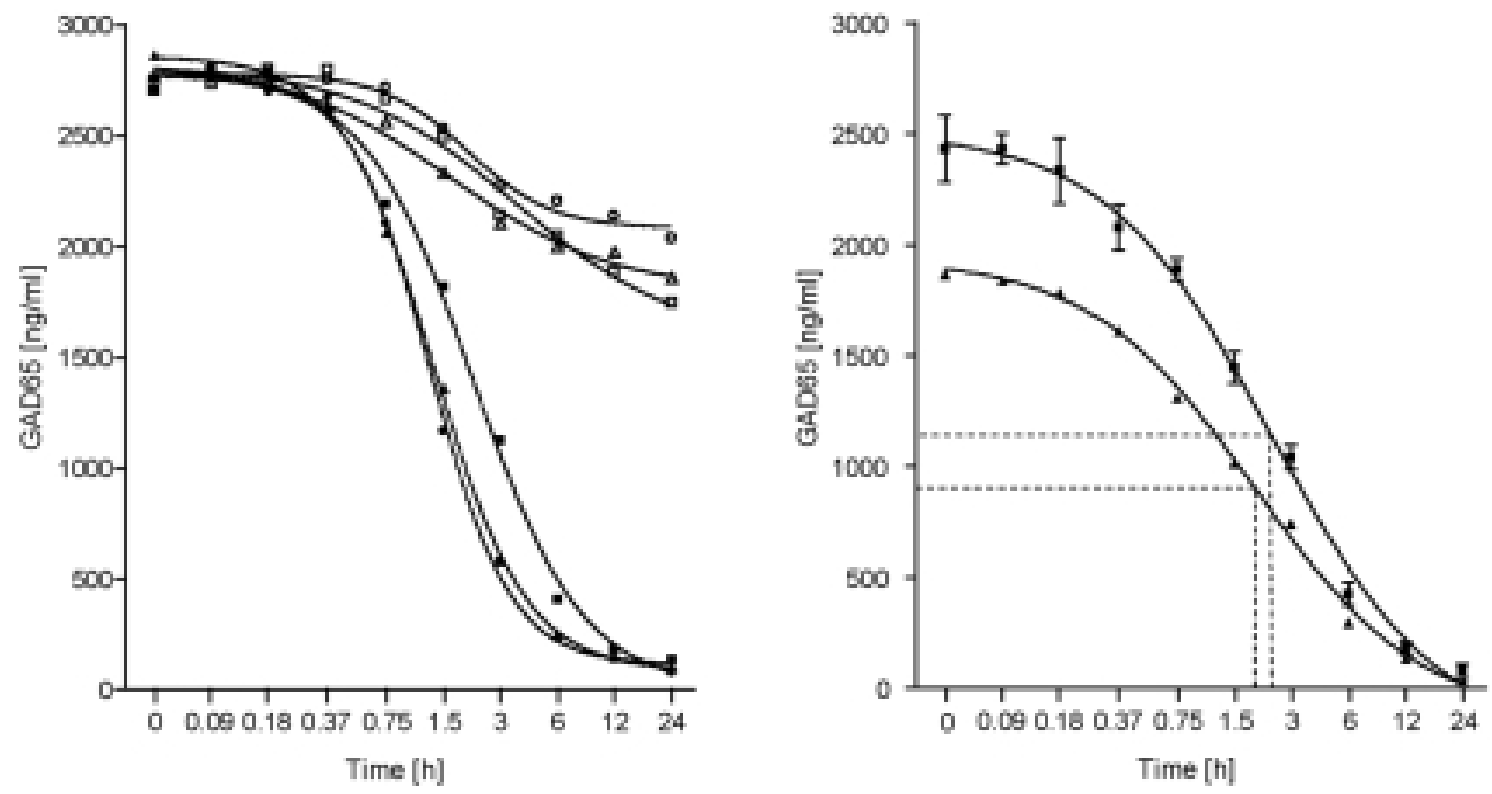

Fig. 1. In vitro degradation kinetics of GAD65 by incubation of blood (squares), plasma (triangles) and serum (circles) of a healthy human donor with a $100,000 \times \mathrm{g}$ supernatant of a porcine cerebellum extract containing $2,772 \mathrm{ng} \mathrm{GAD} 65 / \mathrm{ml}$ at $37 \mathrm{C}$ (filled symbols) and at $4{ }^{\circ} \mathrm{C}$ (open symbols; Fig. 1A). After $24 \mathrm{~h}$ of incubation at $37^{\circ} \mathrm{C}$ only $3.9 \%$ of GAD65 (108 ng/ml) were detectable compared to a recovery of $70.2 \%(1,947$ $\mathrm{ng} / \mathrm{ml})$ after incubation at $4^{\circ} \mathrm{C}$. Data were confirmed by incubation of human recombinant GAD65 (2,500 ng GAD65/ml) with five individual sera of healthy human blood donors (squares; mean $\pm \mathrm{SD}$ ) and a diabetic patients serum containing GADA (triangles) at $3 \% \mathrm{C}$ (Fig. $1 \mathrm{~B}$ ). The dashed lines indicate the half-life of human recombinant GAD65. Data are given as mean of three separate experiments.

Table 1

GAD65 content of $100,000 \times$ g supernatants of pancreatic islet lysates from different species in ng per 1,000 islets and in ng per mg total protein. Data are given as mean content $\pm \mathrm{SD}$ of three separate determinations (n.d. $=$ not detectable)

\begin{tabular}{lcc}
\hline Species & $\begin{array}{c}\text { GAD65 per 1,000 } \\
\text { islets [ng] }\end{array}$ & $\begin{array}{c}\text { GAD65 per mg } \\
\text { protein }[\mathrm{ng}]\end{array}$ \\
\hline Human & $78.0 \pm 7.7$ & $30.1 \pm 2.7$ \\
BB/OK rat & $37.4 \pm 6.3$ & $19.3 \pm 4.1$ \\
LEW.1A rat & $43.7 \pm 4.1$ & $20.4 \pm 4.4$ \\
NOD mouse & n.d. & n.d. \\
Balb/c mouse & n.d & n.d. \\
\hline
\end{tabular}

GAD65/1,000 islets equivalent to $30.1 \mathrm{ng}$ GAD65/mg protein (Table 1). Lower amounts were detected in islets of neonatal BB/OK rats, $37.4 \mathrm{ng}$ GAD65/1,000 islets equivalent to $19.3 \mathrm{ng}$ GAD65/mg protein, and islets of neonatal LEW.1A rats, $43.7 \mathrm{ng} / 1,000$ islets equivalent to $20.4 \mathrm{ng}$ GAD65/mg protein. No GAD65 could be detected in islets of neonatal Balb/c and NOD mice.

\subsection{Degradation kinetics of GAD65 in vitro and in vivo}

The kinetics of GAD65 degradation was measured in vitro by incubation of a GAD65-containing porcine cerebellum extract $(2,772 \mathrm{ng}$ GAD65/ml) in blood, plasma and serum of a healthy human blood donor. The half-life of GAD65 at $37^{\circ} \mathrm{C}$ was $2.16 \mathrm{~h}, 1.32 \mathrm{~h}$ and $1.27 \mathrm{~h}$ in these three situations, respectively, and therefore comparably short (Table 2). Only 3.9\% (108 ng GAD65/ml) was detectable after $24 \mathrm{~h}$ incubation at $37^{\circ} \mathrm{C}$ in contrast to $70.2 \%(1,947 \mathrm{ng} \mathrm{GAD} 65 / \mathrm{ml})$ after incubation at $4^{\circ} \mathrm{C}$ (Fig. 1A). Comparable results were found for incubation of human recombinant GAD65 at $37^{\circ} \mathrm{C}$ with individual serum samples of five healthy human blood donors, with a half-life of $2.35 \mathrm{~h}$, as well as with a GADA-positive serum from a patient with type 1 diabetes, with a half-life of $1.93 \mathrm{~h}$, which were not statistically different (F-test: $p=0.5752$; Fig. 1B). The recovery rate of GAD65 was $97 \%$ in serum of healthy donors and $75 \%$ in the serum of the GADApositive patient. The in vivo half-life of human recombinant GAD65 in rats was 2.77 hours, and no GAD65 was detectable in the circulation of the rats after $24 \mathrm{~h}$ (Fig. 2).

\subsection{GAD65 detection in serum after beta-cell destruction}

In rats treated with a single diabetogenic streptozotocin (STZ) application, the mean blood glucose lev- 
Table 2

Half-life of GAD65 from a porcine cerebellum extract in vitro (human blood, plasma, serum of an individual healthy donor) and human recombinant GAD65 in vitro (human sera from five individual healthy donors and one serum from a GADA-positive patient with type 1 diabetes) and in vivo (after injection into three LEW.1A rats)

\begin{tabular}{lcc}
\hline In vitro & Half-life $[\mathrm{h}]$ & CI (95\%) \\
\hline Porcine GAD65 in whole human blood & 2.16 & $1.75-2.66$ \\
Porcine GAD65 in human plasma & 1.32 & $1.23-1.41$ \\
Porcine GAD65 in human serum & 1.27 & $1.15-1.41$ \\
Human GAD65 in sera from healthy donors & 2.35 & $2.03-2.72$ \\
Human GAD65 in serum from a type 1 diabetic patient & 1.93 & $1.55-2.41$ \\
In vivo & & \\
Human GAD65 in circulation of three LEW.1A rats & 2.77 & $1.70-4.52$ \\
\hline
\end{tabular}

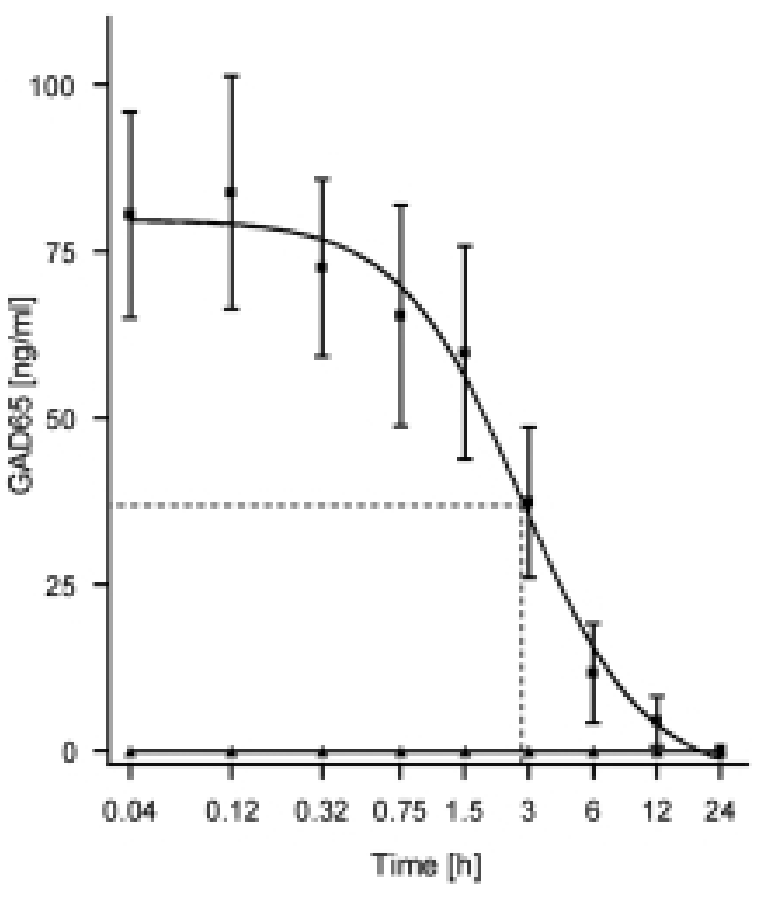

Fig. 2. In vivo degradation kinetics of GAD65 after i.v. application of 2,000 ng of human recombinant GAD65 into 100 day-old female LEW.1A rats ( $n=3$; squares) in comparison to control animals (triangles) which received 2,000 $\mathrm{ng}$ of heat-denaturated $\left(70^{\circ} \mathrm{C}, 15 \mathrm{~min}\right.$ ) human recombinant GAD65 or buffer only. Blood was taken from the retro-orbital sinus and plasma samples were immediately snap frozen until GAD65 determination by the ELISA. After 24 h, no GAD65 was detectable in vivo. Furthermore, no GAD65 was found in the plasma of control animals. The dashed line indicates the half-life. Data are given as mean $\pm \mathrm{SD}$.

els increased from $7.7 \mathrm{mmol} / \mathrm{l}$ before STZ application to $8.2 \mathrm{mmol} / \mathrm{l}$ after $8 \mathrm{~h}, 20.4 \mathrm{mmol} / \mathrm{l}$ after $24 \mathrm{~h}$ and $23.9 \mathrm{mmol} / \mathrm{l}$ after $48 \mathrm{~h}$, indicating a loss of insulin production up to the state of manifest diabetes due to destruction of the vast majority of beta cells. However, no GAD65 was detected in the circulation of these animals over the whole examination period.

\section{Discussion}

GAD65, the smaller $65 \mathrm{kDa}$ isoform of glutamic acid decarboxylase, is a major autoantigen in type 1 diabetes, latent autoimmune diabetes of adulthood (LADA) and prediabetes [1-5]. A number of methods for the detection of autoantibodies against GAD65 (GADA) are available, and the results of measurement are used for predictive and diagnostic purposes in autoimmune diabetes. The aim of this study was to examine the GAD65 content of pancreatic islets from different species, the in vitro and in vivo half-life of GAD65 by determination of its degradation kinetics, and its release into circulation after streptozotocin-induced islet destruction as a model for acute beta-cell loss using a sensitive ELISA. The sandwich ELISA is based on two monoclonal GAD65-specific antibodies with different epitope specificities, one of them solid-phase bound for capturing GAD65 and a second biotin-labelled one for detecting bound GAD65, using alkaline phosphataselabelled streptavidin and a colorimetric substrate [16]. This assay allows the detection of GAD65 with a high sensitivity of $30 \mathrm{pg} / \mathrm{ml}$. Contrary to that, two previously described assays were insufficiently sensitive to detect GAD65 in serum or plasma [11,12].

Recently, new assays for sensitive detection of GAD65 have been reported. Two assays based on time-resolved fluorescence were shown to be suitable for detection of GAD65 in serum with sensitivities of $0.33 \mathrm{ng} / \mathrm{ml}$ and $0.10 \mathrm{ng} / \mathrm{ml}$, respectively [18]. The sensitivity of another assay based on magnetic-beads was the same as our ELISA, but this novel assay uses a monoclonal antibody as primary antibody and a polyclonal serum for detection of bound GAD65 [13]. Furthermore, the assay uses sophisticated techniques like capture of the GAD65 protein with magnetic beads and detection using a chemiluminescent enzyme substrate, which require extensive washing steps and a considerable amount of time and hands-on work. While the 
authors demonstrated the usefulness of their assay for examination of serum and plasma samples, no data on the kinetics of GAD65 degradation in vitro or in vivo have been reported so far.

In the present study, we first examined the GAD65 content of isolated islets (Table 1). The highest amount was found in human islets, 78.0 ng GAD65/1,000, while lower levels were detected in islets of neonatal LEW.1A and BB/OK rats, ranging from $37.4 \mathrm{ng}$ to $43.7 \mathrm{ng}$ GAD65/1,000 islets, respectively. In contrast, no GAD65 could be detected in islets of neonatal Balb/c and NOD mice, although the assay allows us to detect mouse GAD65 in brain tissue [16]. This result confirms the recent report by Waldrop et al. [13] as well as immunohistochemical findings that mouse islets do not express GAD65 in detectable amounts [15, 16]. Thus, considering the detection limit of our assay, the amount of GAD65 in one mouse islet must be lower than $0.015 \mathrm{pg}$. The GAD65 content of one mouse islet is therefore at least 2,500 fold lower than that of one $\mathrm{BB} / \mathrm{OK}$ rat islet. Contrary to our findings, very low levels of GAD65 were detected in mouse islets in another study [19]. In addition, the generation of our anti-GAD65-MAb M61/7E11 by treatment of a NOD mouse with STZ and complete Freund's adjuvant suggests that GAD65 might be present in mouse islets under certain conditions [15]. However, unlike humans and rats, GAD65 is not the main isoform of GAD in mouse islets.

The examination of the GAD65 degradation kinetics in vitro using porcine GAD65 in blood, plasma and serum of a healthy human blood donor revealed that the half-life of GAD65 at $37^{\circ} \mathrm{C}$ was comparably short in all three situations (Table 2). Furthermore, the GAD65 degradation was greatly diminished at $4^{\circ} \mathrm{C}$ compared to $37^{\circ} \mathrm{C}$ (Fig. 1A). Whereas $70.2 \%$ of GAD65 were detectable after $24 \mathrm{~h}$ incubation at $4{ }^{\circ} \mathrm{C}$, only $3.9 \%$ were found following $37^{\circ} \mathrm{C}$ incubation. The fact that the kinetics in serum is temperature-dependent indicates that the clearance of GAD65 in these experiments is most probably due to enzymatic degradation. Although there was a difference observed between whole blood and serum or plasma, the overall degradation kinetics in the three samples was found to be similar. Comparable results were found using human recombinant GAD65 with individual serum samples of five healthy human blood donors as well as with a GADA-positive serum from a patient with type 1 diabetes. Although the total level of GAD65 found after incubation with the patient's serum was lower than after incubation with serum samples from healthy control probands, the time course of GAD65 degradation was comparable and its half-life in both experiments was not significantly different. Furthermore, results from an earlier study demonstrated that the median level of displacement of the monoclonal antibody M61/7E11, which was used as detector in the present study, by GADA-positive sera did not differ from those of GADA-negative sera. Only $10 \%$ (3/30) of GADA-positive serum samples from newly diagnosed type 1 diabetic patients did show a moderate level of competition [20]. Taken together, these results suggest that the presence of GADA might affect the recovery in our assay but does not influence the GAD65 degradation kinetics (Fig. 1B). The recovery rates which we observed in these experiments are in line with the previously reported work of Waldrop et al. [13].

With an in vivo half-life of 2.77 hours, the degradation of human recombinant GAD65 in the circulation of rats was comparable to the in vitro data (Fig. 2). A similarly short half life was found previously for other cytosolic enzymes which are discharged into the circulation following tissue injury, such as cardiac troponin $\mathrm{T}$ in human $(2 \mathrm{~h})$ or lactate dehydrogenase ranging from $0.5 \mathrm{~h}$ in rats to $3.2 \mathrm{~h}$ in rabbits $[21,22]$. While excretion, or liver catabolism as found for other cytosolic enzymes [22], might play a role in the clearance of GAD65 from the circulation, the fact that the in $v i$ vo kinetics data are comparable to the in vitro results indicates that degradation in serum is most likely the main process responsible for the rapid disappearance of GAD65. The slightly higher half-life in vivo can probably be explained by the time required for distribution in the circulation before GAD65 reaches measurable levels at the site of blood sampling.

In rats which were treated with a single diabetogenic streptozotocin (STZ) application, we observed an increase of their mean blood glucose levels over 48 hours up to the state of manifest diabetes indicating a loss of insulin production. In previous studies it was described that the majority of beta cells undergoes necrosis and lysis within twenty-four hours after a single high-dose application of STZ [23-25]. Furthermore, first visible histological lesions, a distinct increase in serum insulin and a dramatic decrease in the islet content of gammaaminobutyric acid, the product catalyzed by GAD, was already observed after seven hours [24]. However, in the time schedule used in our experiments, no GAD65 was detected in the circulation of STZ-treated LEW.1A rats over the whole examination period. A possible reason is the elimination of GAD65 on site along with the described clearance of the remnants of destroyed 
beta cells by macrophages [25]. An alternative explanation might be that the GAD65 which is released from destroyed beta cells is transported mainly to the lymphnodes. In that case a detection of GAD65 in the circulation is unlikely. Therefore, it would be interesting in future studies to locate the fate of GAD65 after beta-cell destruction.

Considering a total blood volume of approximately $20 \mathrm{ml}$ per rat and a GAD65 content of $43.7 \mathrm{pg}$ in one rat islet (Table 1), the expected maximum GAD65 serum concentration after destruction of one islet would be about $2.2 \mathrm{pg} / \mathrm{ml}$. Taking the assay's detection limit into account, the total GAD65 content of at least 13 simultaneously destroyed islets would be required to detect GAD65 in the circulation. In an average human being with a body weight of $70 \mathrm{~kg}$ and a blood volume of $69 \mathrm{ml} / \mathrm{kg}$ body weight, the theoretical GAD65 concentration in serum after destruction of one islet with a GAD65 content of 78 pg (Table 1) would be about $0.016 \mathrm{pg} / \mathrm{ml}$. Thus, the total GAD65 content of at least 1,875 simultaneously destroyed islets, equivalent to about $0.2 \%$ of total islets of an average human being, would be required to detect GAD65 in human serum. In addition to this estimation, the short halflife of GAD65 at physiological conditions must also be taken into account. In this regard, a direct implication of the current study for future investigations is the importance of immediate cooling of the blood and serum samples and handling at low temperatures during the analytical procedures in order to reduce the degradation of the GAD65 protein.

An experimental study of islet transplantation using a dog model already indicated that an elevation of the GAD enzymatic activity in serum can precede graft rejection [6]. Therefore, GAD65 determination by sensitive immunoassays to detect graft rejection after islet transplantation should be the subject of further investigations. Additionally, studies involving the examination of sera from high-risk prediabetic subjects characterized by a genetic predisposition as well as multiple autoantibodies to islet antigens such as GAD65, protein tyrosine phosphatase IA-2 and insulin, will help to assess the diagnostic relevance of GAD65 serum levels in the context of autoimmune diabetes.

\section{Acknowledgements}

We are grateful to Ms H. Kenk and S. Tietz for their excellent technical assistance.

\section{References}

[1] S. Baekkeskov, H.J. Aanstoot, S. Christgau, A. Reetz, M. Solimena, M. Cascalho, F. Folli, H. Richter-Olesen and P. de Camilli, Identification of the $64 \mathrm{~K}$ auto antigen in insulindependent diabetes as the GABA-synthesizing enzyme glutamic acid decarboxylase, Nature 347 (1990), 151-156.

[2] W.A. Hagopian, B. Michelsen, A.E. Karlsen, F. Larsen, A. Moody, C.E. Grubin, R. Rowe, J. Petersen, R. McEvoy and A. Lernmark, Autoantibodies in IDDM primarily recognize the $65,000-\mathrm{M}(\mathrm{r})$ rather than the $67,000-\mathrm{M}(\mathrm{r})$ isoform of glutamic acid decarboxylase, Diabetes 42 (1993), 631-636.

[3] L.A. Velloso, O. Kämpe, A. Hallberg, L. Christmanson, C. Betsholtz and F.A. Karlsson, Demonstration of GAD-65 as the main immunogenic isoform of glutamate decarboxylase in type 1 diabetes and determination of autoantibodies using a radioligand produced by eukaryotic expression, Journal of Clinical Investigation 91 (1993), 2084-2090.

[4] F. Lühder, M. Schlosser, L. Mauch, H. Haubruck, I. Rjasanowski, D. Michaelis, K.D. Kohnert and M. Ziegler, Autoantibodies against GAD65 rather than GAD67 precede the onset of Type I diabetes, Autoimmunity 19 (1994), 71-80.

[5] P.Z. Zimmet, T. Tuomi, I.R. Mackay, M.J. Rowley, W. Knowles, M. Cohen and D.A. Lang, Latent autoimmune diabetes mellitus in adults (LADA): the role of antibodies to glutamic acid decarboxylase in diagnosis and prediction of insulin dependency, Diabetic Medicine 11 (1994), 299-303.

[6] A.M. Shapiro, E.G. Hao, J.R. Lakey, W.J. Yakimets, T.A. Churchill, P.G. Mitlianga, G.K. Papadopoulos, J.F. Elliott, R.V. Rajotte and N.M. Kneteman, Novel approaches toward early diagnosis of islet allograft rejection, Transplantation $\mathbf{7 1}$ (2001), 1709-1718.

[7] J.S. Petersen, K.R. Hejnaes, A. Moody, A.E. Karlsen, M.O. Marshall, M. Hoier-Madsen, E. Boel, B.K. Michelsen and T. Dyrberg, Detection of GAD65 antibodies in diabetes and other autoimmune diseases using a simple radioligand assay, Diabetes 43 (1994), 459-467.

[8] A. Falorni, E. Ortqvist, B. Persson and A. Lernmark, Radioimmunoassays for glutamic acid decarboxylase (GAD65) and GAD65 autoantibodies using $35 \mathrm{~S}$ or $3 \mathrm{H}$ recombinant human ligands, Journal of Immunological Methods 186 (1995), 89-99.

[9] M. Ankelo, A. Westerlund-Karlsson, J. Ilonen, M. Knip, K. Savola, P. Kankaanpaa, L. Merio, H. Siitari and A. Hinkkanen, Time-resolved fluorometric assay for detection of autoantibodies to glutamic acid decarboxylase (GAD65), Clinical Chemistry 49 (2003), 908-915.

[10] P.J. Bingley, E. Bonifacio and P.W. Mueller, Diabetes Antibody Standardization Program: first assay proficiency evaluation, Diabetes 52 (2003), 1128-1136.

[11] A.J. Moody, K.R. Hejnaes, M.O. Marshall, F.S. Larsen, E. Boel, I. Svendsen, E. Mortensen and T. Dyrberg, Isolation by anion-exchange of immunologically and enzymatically active human islet glutamic acid decarboxylase 65 overexpressed in Sf9 insect cells, Diabetologia 38 (1995), 14-23.

[12] W. Hao, T. Daniels and D.G. Pipeleers, A Smismans, H. Reijonen, G.T. Nepom, A. Lernmark, Radioimmunoassay for glutamic acid decarboxylase-65, Diabetes Technology \& Therapeutics 1 (1999), 13-20.

[13] M.A. Waldrop, A.T. Suckow, T.R. Hall, C.S. Hampe, S.M. Marcovina and S.D. Chessler, A highly sensitive immunoassay resistant to autoantibody interference for detection of the diabetes-associated autoantigen glutamic acid decarboxylase 
65 in blood and other biological samples, Diabetes Technology \& Therapeutics 8 (2006), 207-218.

[14] D.I. Gottlieb, Y.C. Chang and J.E. Schwob, Monoclonal antibodies of glutamic acid decarboxylase, Proceedings of the National Academy of Sciences 83 (1986), 8808-8812.

[15] B. Ziegler, P. Augstein, F. Lühder, W. Northemann, J. Hamann, M. Schlosser, I. Kloting, D. Michaelis and M. Ziegler, Monoclonal antibodies specific to the glutamic acid decarboxylase $65 \mathrm{kDa}$ isoform derived from a non-obese diabetic (NOD) mouse, Diabetes Research 25 (1994), 47-64.

[16] M. Schlosser, J. Hahmann, B. Ziegler, P. Augstein and M. Ziegler, Sensitive monoclonal antibody-based sandwich ELISA for determination of the diabetes-associated autoantigen glutamic acid decarboxylase GAD65, Journal of Immunoassay 18 (1997), 289-307.

[17] L. Mauch, C.C. Abney, H. Berg, W.A. Scherbaum, B. Liedvogel and W. Northemann, Characterization of a linear epitope within the human pancreatic 64-kDa glutamic acid decarboxylase and its autoimmune recognition by sera from insulindependent diabetes mellitus patients, European Journal of Biochemistry 212 (1993), 597-603.

[18] M. Rui, C.S. Hampe, C. Wang, Z. Ling, F.K. Gorus, A. Lernmark, D.G. Pipeleers and P.E. De Pauw, Species and epitope specificity of two $65 \mathrm{kDa}$ glutamate decarboxylase timeresolved fluorometric immunoassays, Journal of Immunological Methods 319 (2007), 133-143.

[19] J. Kim, W. Richter, H.J. Aanstoot, Y. Shi, Q. Fu, R. Rajotte, G. Warnock and S. Baekkeskov, Differential expression of
$\mathrm{GAD}_{65}$ and $\mathrm{GAD}_{67}$ in human, rat and mouse pancreatic islets, Diabetes 42 (1993), 1799-1808.

[20] B. Ziegler, M. Schlosser, F. Lühder, M. Strebelow, P. Augstein, W. Northemann, A.C. Powers and M. Ziegler, Murine monoclonal glutamic acid decarboxylase (GAD)65 antibodies recognize autoimmune-associated GAD epitope regions targeted in patients with type 1 diabetes mellitus and stiff-man syndrome, Acta Diabetologia 33 (1996), 225-231.

[21] R. Zimmermann, S. Baki, T.J. Dengler, G.H. Ring, A. Remppis, R. Lange, S. Hagl, W. Kübler and H.A. Katus, Troponin T release after heart transplantation, British Heart Journal 69 (1993), 395-398.

[22] M.J. Smit, H. Beekhuis, A.M. Duursma, J.M. Bouma and M. Gruber, Catabolism of circulating enzymes: plasma clearance, endocytosis, and breakdown of lactate dehydrogenase- 1 in rabbits, Clinical Chemistry 34 (1988), 2475-2480.

[23] H.H. von Dorsche, Histotopochemical and electronmicroscopical investigations of Wistar-rats with streptozotocin diabetes, Acta Histochemica 64 (1979), 5-19.

[24] H. Taniguchi, Y. Okada, H. Seguchi, C. Shimada, M. Seki, A. Tsutou and S. Baba, High concentration of gammaaminobutyric acid in pancreatic beta cells, Diabetes 28 (1979), 629-633.

[25] M.C. Dutrillaux, B. Portha, C. Roze and E. Hollande, Ultrastructural study of pancreatic B cell regeneration in newborn rats after destruction by streptozotocin, Virchows Archiv B Cell Pathology including Molecular Pathology 39 (1982), 173-185. 


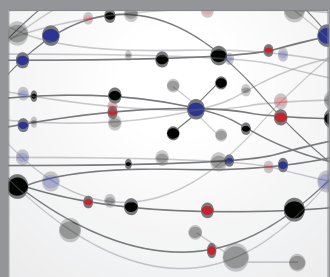

The Scientific World Journal
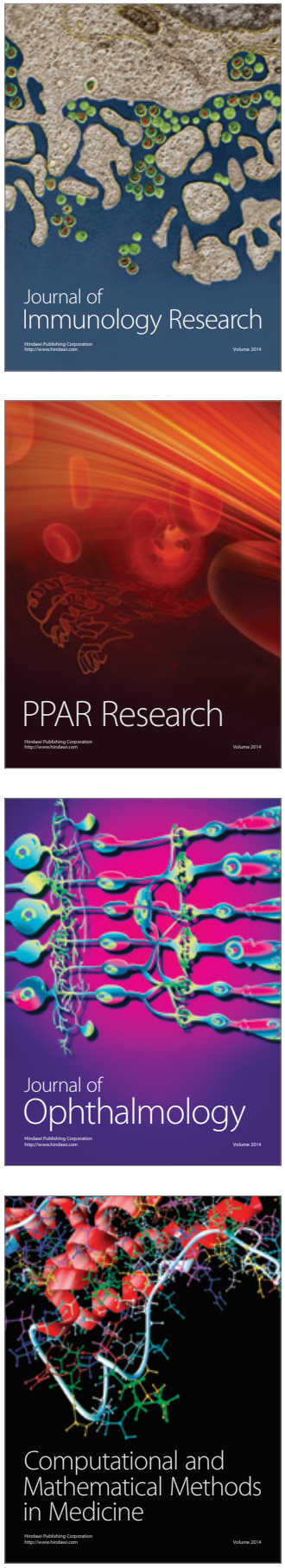

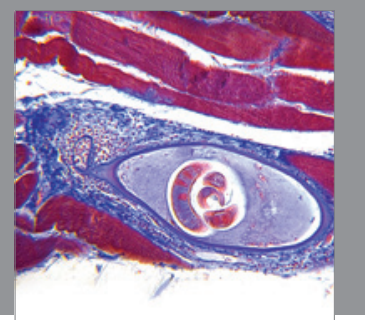

Gastroenterology

Research and Practice
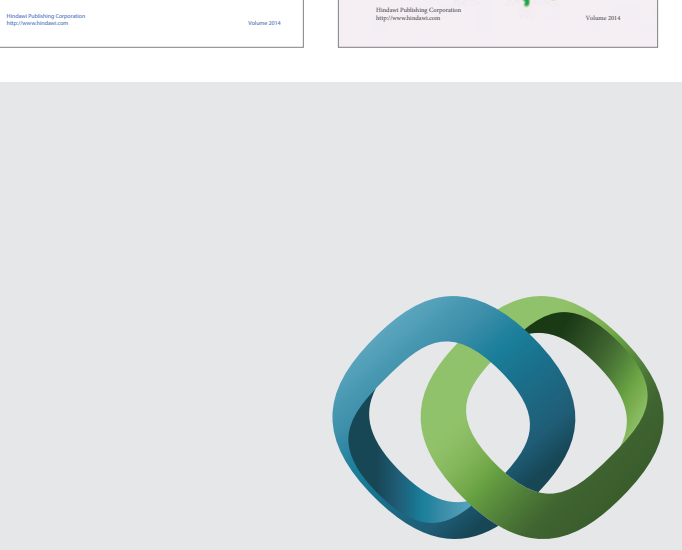

\section{Hindawi}

Submit your manuscripts at

http://www.hindawi.com
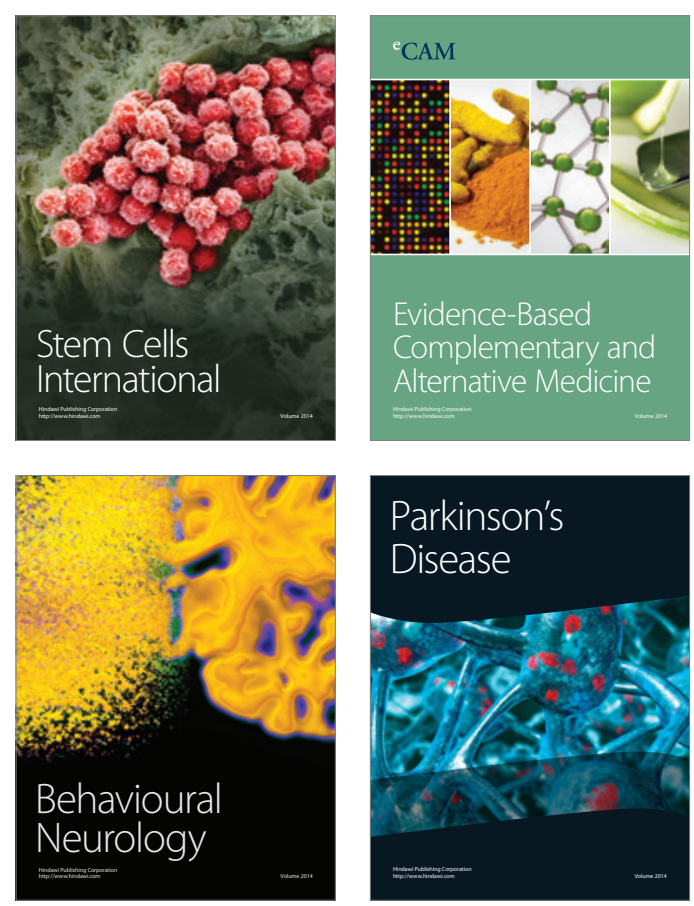

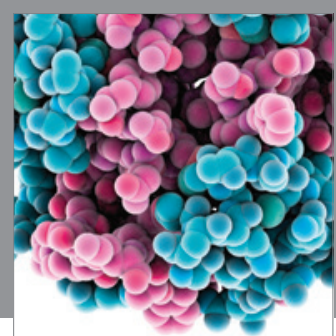

Journal of
Diabetes Research

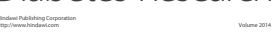

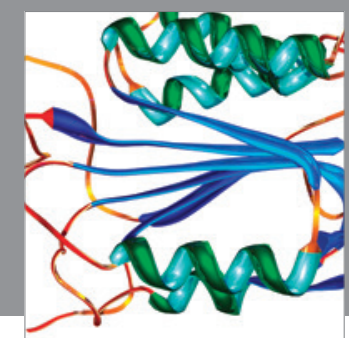

Disease Markers
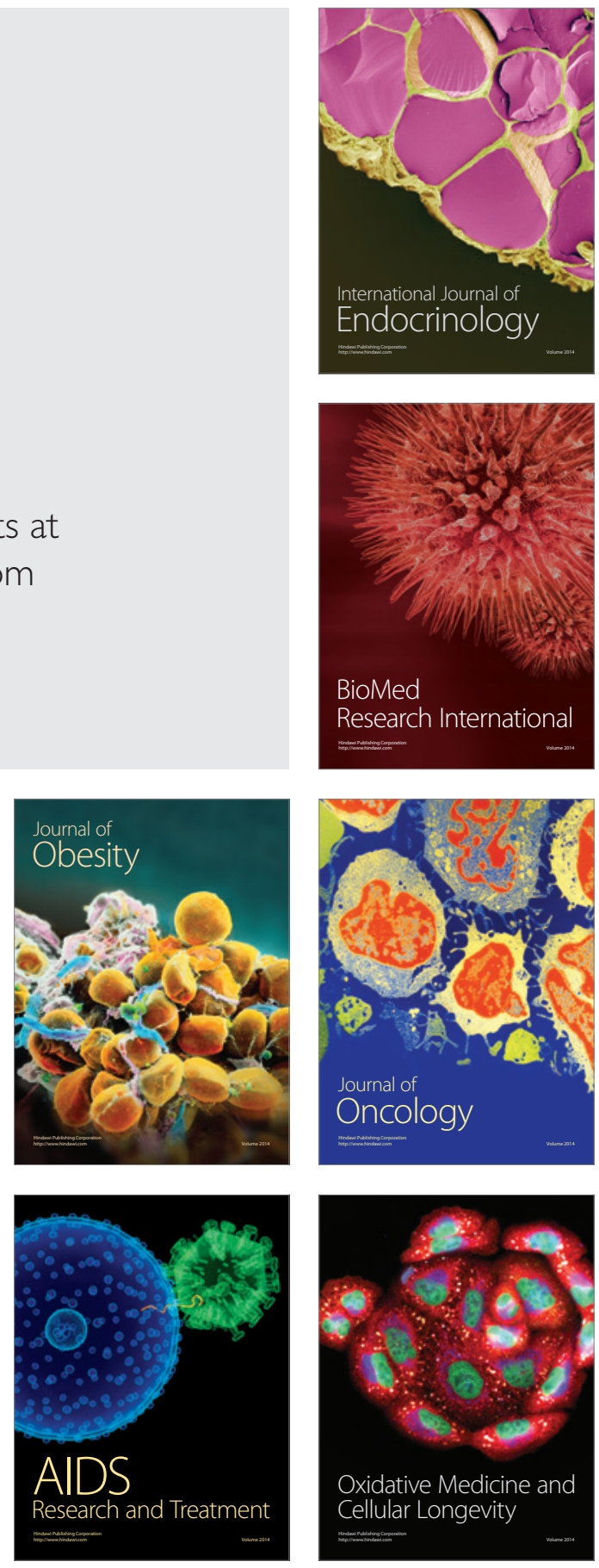